\section{Whisker-mediated transformation of peanut with chitinase gene enhances resistance to leaf spot disease}

\author{
Mahmood ul Hassan ${ }^{1}$, Zahid Akram ${ }^{1}$, Shaukat Ali ${ }^{2}$, Ghulam \\ Muhammad Ali ${ }^{2}$, Yusuf Zafar ${ }^{2}$, Zahid Hussain Shah ${ }^{1,3^{*}}$ and \\ Fahad Alghabari ${ }^{3}$
}

\begin{abstract}
Peanut (Arachis hypogaea) is an important legume and oilseed crop, native to South America and grown in all tropical and temperate regions of the world. A simplified and rapid direct gene delivery system in peanut was developed by vortexing silicon carbide whiskers with callus and with plasmid harboring chitinase and hygromcin genes. The effects of callus age and whisker quantity on transformation efficiency were evaluated. Transformation efficiency (6.88\%) was highest when $200 \mathrm{mg}$ of whiskers were used with $5 \mu \mathrm{g}$ plasmid for $2 \mathrm{~g}$ of 20-day-old callus. Hygromcin-resistant calli were regenerated to complete plants which produced seeds normally. Transgene insertion and number of transgene copieswere confirmed by PCR and southern blot analyses, respectively. Transgene expression was evaluated by a pathogenecity test and RT-PCR analysis. In transgenic events, the resistance level to leaf spot disease was far higher than in control plants.
\end{abstract}

Key words: Transgenic, callus, reporter gene, cell wall.

\section{INTRODUCTION}

Because of the narrow genetic base, improvement in peanut by conventional breeding is not as rapid as needed to meet the demands of a growing population (Asif et al. 2011, Banjara et al. 2012). Genetic transformation is the most appropriate option for breeding of many important traits that are not improved by conventional methods. The establishment of a suitable gene delivery system and a protocol for the subsequent recovery of plants is a basic requirement for the recalcitrant varietiesof peanut (Branch 1996).

The plant cell wall is frequentlyaninanimate obstacle in experiments with DNA delivery technologies for plant genetic engineering. In case of biological systems, the cell wall is dissolved by enzymes, secreted by mediating prokaryotes, which allows DNA delivery to recipient cells (Dunwell 2011). The cell wall problem was circumvented by usingprotoplasts for DNA bombardment in non-agrobacterium transformation methods. Protoplasts are excellent targets for genetic transformation, whereas plant regeneration from protoplasts is problematic (Choi et al. 1997). Genegun-mediated transformation is also receiving increasing attention, but requires sophisticated expertise, expensive equipment and consumables. Silicon carbide whiskers on the other hand are extremely well-suited means of direct gene delivery, for being very simple and
Crop Breeding and Applied Biotechnology 16: 108-114, 2016 Brazilian Society of Plant Breeding. Printed in Brazil http://dx.doi.org/10.1590/198470332016v16n2a17 \title{
.
}


not requiring much technical equipment and skills (Kaeppler et al. 1990). These whiskers are basically 10-80 mm long and $0.6 \mathrm{~mm}$ widemicrofibers (Coffee and Dunwell 1994).

Silicon carbide whiskers are inherently hard and easily cleavable, producing sharp cutting edges (Greenwood and Earnshaw 1984). The mechanism for whisker-mediated transformation is based on the micro puncturing of cells for DNA delivery. The surface of silicon carbide whiskers is negatively charged so it cannot bind to DNA for ultimate delivery into the host cell (Appel et al. 1988, Mutsuddy 1990). Kaeppler et al. (1992) also refuted the benefit of premixing DNA with whiskers. This means that whiskers puncture the cell only during vortexing, opening the way for DNA entry. However, to develop a protocol for consistent transgenic plant production, some marker genes were used (Dalton et al. 1998). In this sense, the conditions for a successful whisker-mediated DNA transformation have been studied using the transient expression of reporter genes (Nagatani et al. 1997, Iqbal et al. 2012). Moreover, for the whisker method, tissue culture with specific morphological features has to be produced and maintained, as well as conditions that favor an efficient delivery of DNA to target cells (Petolino 2002). In addition, an effective means of isolation is a pre-requisite for the recovery of infrequent integration events (Thompson et al. 1997).

When peanut is exposed to fungal attack, the plants accumulate pathogenesis-related proteins such as chitinases (Brunner et al. 1998), indicating antifungal activity (Yun et al. 1996). In tobacco plants, on the other hand, different chitinase isoforms were identified bystructural gene analysis, although only particular isoforms exhibited antifungal activity (Sela-Buurlage 1993, Chu et al. 2013, Parasad et al. 2013).

The purpose of this study was to develop a rapid, simple, economical and less laborious protocol for a highly efficient silicon carbide whisker-mediated transformation of a peanut cultivar.

\section{MATERIAL AND METHODS}

\section{Production of embryogenic callus}

The epicotyl explants of four commercial peanut varieties (BARD-92, BARI-2000, BARD-479, and Golden) were cultured on callus induction medium (CIM) consisting of MS (Murashige and Skoog 1962), macro- and micro-salts, B5 vitamins (Gamborg et al. 1968), and 30 $\mathrm{L} \mathrm{L}^{-1}$ sucrose, and supplemented with $8 \mathrm{mg} \mathrm{L}^{-1}$ picloram, as previously standardized by Hassan et al. (2013). Thereafter, $8 \mathrm{~g} \mathrm{~L}^{-1}$ agar was added after adjusting the $\mathrm{pH}$ to 5.8 at $25^{\circ} \mathrm{C}$. The explants were inoculated on medium for 3 weeks at $25 \pm 2{ }^{\circ} \mathrm{C}$, with a photoperiod of $16 / 8$ hours. The medium, growth regulators and agar were supplied by Phytotech Lab, USA.

\section{Preparation of silicon carbide whiskers and DNA delivery}

Different quantities of silicon carbide whiskers (100, 200 and $300 \mathrm{mg}$ ) were added to pre-weighed 50-mL plastic tubes, covered with aluminum foil and autoclaved at $121^{\circ} \mathrm{C}$ for $15 \mathrm{~min}$. Five $\mathrm{ml}$ of separately autoclaved callus induction medium and $5 \mu \mathrm{g}$ of the binary vector plasmid (pB1333) harboring rice chitinase and hygromycin phosphotransferase (hpt) genes driven by EN4 and CaMV 35S promoters, respectively, were added to this tube and vortexed for 2 min. Two gram of embryogenic callus (10,20, and 30 days old) was added to this tube and vortexed again for 2 min and incubated on CIM for 24 hours at $25^{\circ} \mathrm{C}$. The control experiment was performed without plasmid DNA.

\section{Selection for stable transformants}

Treated callus clumps were transferred to petri plates containing callus induction medium with $30 \mathrm{mg} \mathrm{L}^{-1}$ hygromycin (lethal dose). Surviving calli were sub-cultured on fresh medium after 2 weeks. The hygromycin-resistant calli were transferred to embryo conversion medium (ECM) consisting of MS salts, B5 vitamins, 30g L L ${ }^{-1}$ sucrose and $1.5 \mathrm{mg} \mathrm{L}^{-1} 2,4-$ D, as standardized by Hassan et al. (2013). The developed embryos were transferred to embryo germination medium (EGM) consisting of MS salts, B5 vitamins, $30 \mathrm{~g} \mathrm{~L}^{-1}$ sucrosesupplemented with $0.1 \mathrm{mg}$ BAP, as determined by Hassan et al. (2013). After 3 weeks, the germinated embryos were planted in coconut husk compost.

\section{PCR Analysis}

The DNA from putative $\left(T_{0}\right)$ and control peanut plants was isolated by the CTAB method. For PCR analysis of chitinase 
in the genome of transformants, forward primer 5'-CATATCAAGCATGAGGTGTA-3' and reverse primer $5^{\prime}$-CAACAACGATTTT GCTATAA-3' were used to amplify a 696 bp fragment. DNA was first denatured at $94{ }^{\circ} \mathrm{C}$ for 3 min and then for $30 \mathrm{~s}$ in each cycle. Annealing temperature was $52^{\circ} \mathrm{C}$ for $30 \mathrm{~s}$, while extension was run for $45 \mathrm{~s}$ at $72{ }^{\circ} \mathrm{C}$. After 40 cycles, a final extension step was added at $72{ }^{\circ} \mathrm{C}$ for $20 \mathrm{~min}$.

\section{Selection of $\mathrm{T}_{1}$ Plants}

Lateral twigs of 25-day-old $\mathrm{T}_{1}$ plants were cut, and thetrimmed end was submerged in Hoagland solution containing $150 \mathrm{mg} \mathrm{L}^{-1}$ hygromycin in test tubes. Plants with symptoms of discoloration, necrosis and wilting were discarded, while those with normal green color and vigor were selected and planted inlarger $(25 \times 25 \mathrm{~cm})$ earthen pots.

\section{Pathogenicity test for intact plants}

The $\mathrm{T}_{1}$ plants from which twigs were cut for the above test were tested for pathogenicity. Spores of Cercosporadium personatum were extracted by thoroughly washing a large number of infected leaves and collecting the spores from the distilled autoclaved water. Spore concentration was measured by a haemocytometer and adjusted to a concentration of $2 \times 10^{5}$ spores $\mathrm{mL}^{-1}$. The resistance of control and transgenic plants was evaluated by spraying spore suspension on the leaves until run-off. An air humidity of $100 \%$ was maintained with a humidifier in the green house. The necrotic area (\%) was calculated by multiplying the mean lesion size by the number of lesions divided by the leaf area.

\section{RT-PCR analysis}

The RNA from control and confirmed transgenic $\left(T_{1}\right)$ plants was extracted with TRI reagent ${ }^{\circledR}$ (Sigma-Aldrich). The cDNA was synthesized using a Omniscript ${ }^{\circledR}$ Reverse Transcription Kit (Qiagen) according to the manufacturer's instructions. The total reaction volume of $20 \mu \mathrm{L}$ contained $2 \mu \mathrm{g}$ RNA, $2 \mu \mathrm{L} \mathrm{10x} \mathrm{RT} \mathrm{buffer,} 2 \mu \mathrm{L}$ dNTP Mix, $2 \mu \mathrm{L}$ oligo-dT primer (10 $\mu \mathrm{M})$, $1 \mu \mathrm{L}$ RNase inhibitor ( 10 units $\mu \mathrm{L}^{-1}$ ), and $1 \mu \mathrm{L}$ reverse transcriptase. Polymerase chain reaction was performed using the primers mentioned in the section PCR analysis, and the product was separated on $1 \%$ agarose gel.

\section{RESULTS AND DISCUSSION}

Analysis of variance showed that callus age, whisker quantity and their interactions had highly significant effects on transformation efficiency (Table 1). The transformation efficiency was highest (6.88\%) when $200 \mathrm{mg}$ of whiskers were used for 20 -day-old callus and lowest $(2.00 \%)$ when using $100 \mathrm{mg}$ of whiskers on 30-day-old callus (Figure 1). The turgidity of 20-day-old callus cells seems to be optimal, facilitating whisker piercing to deliver the desired foreign DNA (Asad et al. 2008).

Callus cells at the age of 10 days are fully turgid and thus more prone to excessive damage by whisker piercing (Petolino et al. 2000). On the other hand, 30-day-old callus cells lose much of their turgidity and are least wounded by whiskers, decreasing the transformation efficiency.

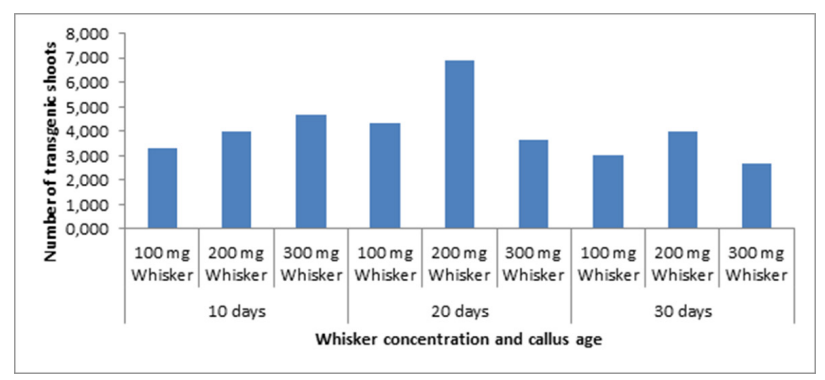

Figure 1. Effect of callus age and whisker concentration on numberof hygromycin-resistant shoots (\%).

Table 1. Analysis of variance for factors affecting transformation efficiency

\begin{tabular}{|c|c|c|c|c|}
\hline Source of variation & df & Sum of Squares & Mean Square & F Value \\
\hline Callus age & 2 & 15.50 & 7.75 & $20.92 * *$ \\
\hline Whisker quantity & 2 & 10.66 & 5.33 & $14.40 * *$ \\
\hline Interaction & 4 & 11.66 & 2.91 & $7.87^{* *}$ \\
\hline Error & 18 & 6.66 & 0.37 & 35.41 \\
\hline Total & 26 & 44.50 & 3.02 & 34.42 \\
\hline
\end{tabular}

** Highly significant 


\section{$\mathrm{T}_{0}$ generation}

Embryos with normal growth in selective medium (Figure 2) were subcultured on the same medium to confirm their resistance to hygromycin. Only three hygromycin-resistant embryos were successfully converted to full-fledged plants in which the expected 696 bp band was confirmed by PCR analysis (Figure 3). These plants were rooted in coconut husk compost, where they reached maturity and produced seeds normally. Southern blot analysis indicated a single copy of the gene only in plant number $\mathrm{T}_{0}-3$, while two copies were observed in the other two plants (Figure 4).

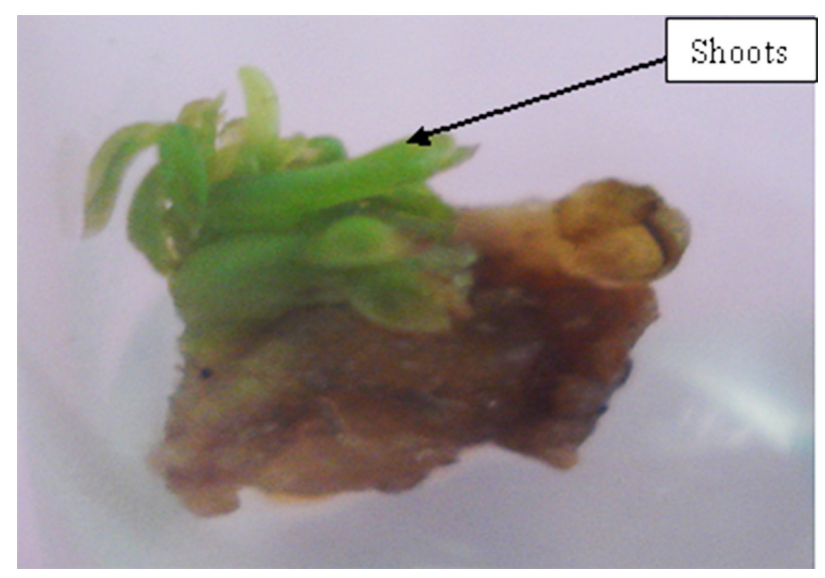

Figure 2. Emergence of hygromcine resistant shoots in selection medium.

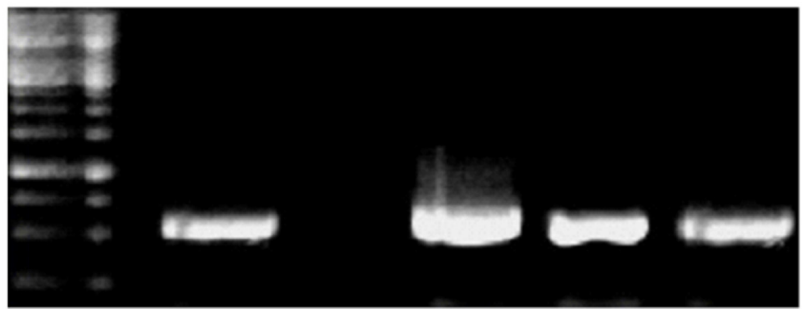

Figure 3. Amplification of RCG 3 gene fragment by PCR in three surviving $T_{0}$ plants. L: 1 kb ladder; (+): Plasmid containing RCG3 gene; (-): control plant; Lanes 1-3: transgenic plants $\left(T_{0}-1\right.$ to $\left.T_{0}-3\right)$.

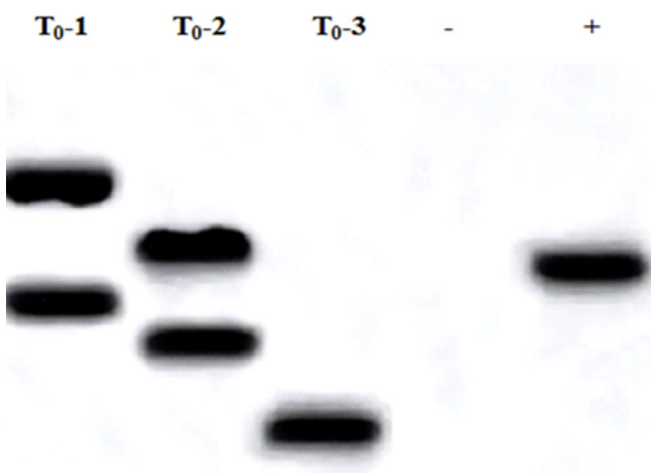

Figure 4. Southern blot analysis of three PCR positive plants.

\section{$\mathrm{T}_{1}$ generation}

Among the progeny plants of $T_{0}-3$, six were resistant and five sensitive to hygromycin. Polymerase chain reaction analysis for the presence of gene RCG-3 revealed the expected $696 \mathrm{bp}$ band in the hygromycin-resistant plants, while no band was observed in the sensitive plants (Figure 5).

\section{Pathogenicity test}

The uppermost leaf node, with four leaflets, was tagged on three main branches per plant for disease evaluation (Figure 6). The incubation frequency (IF, number of lesions per $\mathrm{cm}^{2}$ of leaf area), incubation period (IP), lesion diameter (LD), leaf area damage (LAD), and disease score
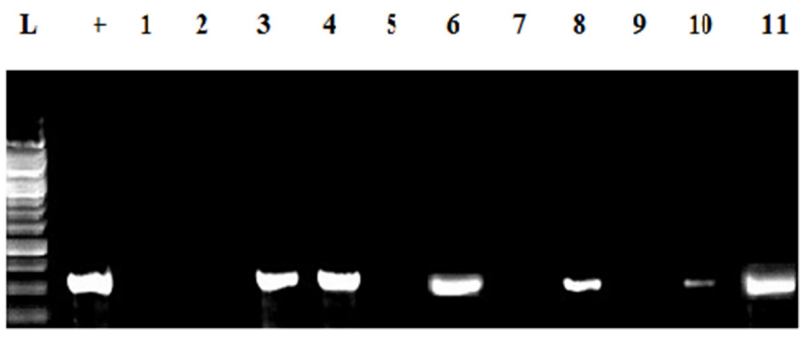

Figure 5. Amplification of RCG 3 gene fragment by PCR in $T_{1}$ plants. L: 1 kb ladder; (+): Plasmid containing RCG3 gene; Lanes 1-11: T1 plants.
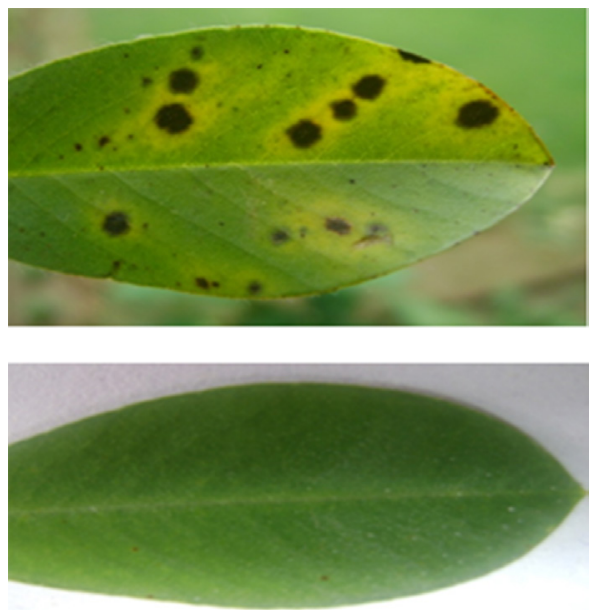

Figure 6. Pathogenicity test of intact plants for susceptibility to late leaf spot disease: control (above) and transgenic (below) plants. 


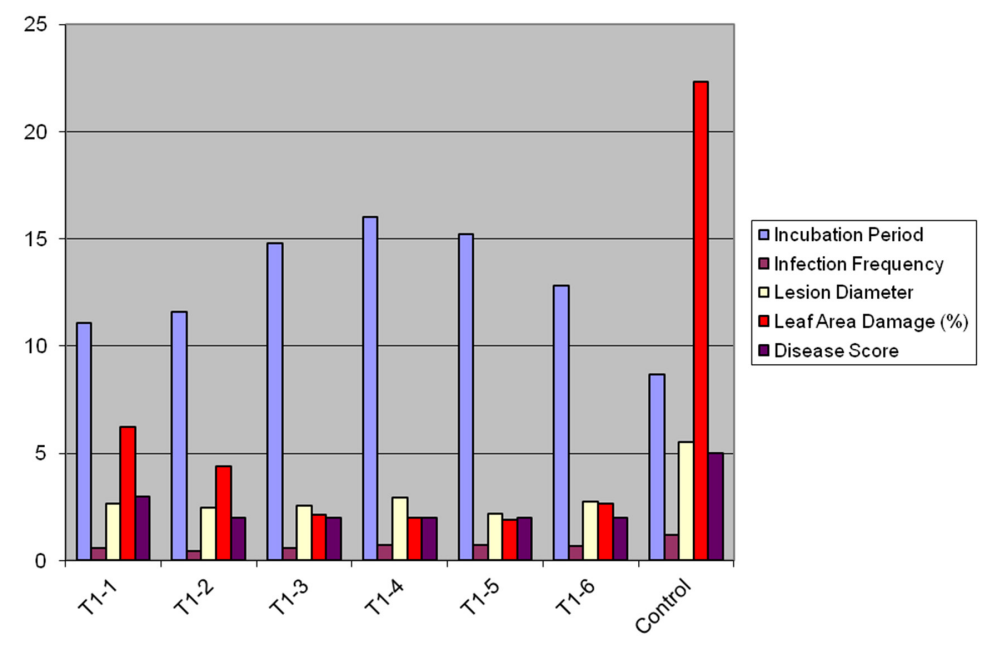

Figure 7. Means ofinfection frequency, incubation period, lesion diameter, leaf area damage, and disease score of transgenic and control plants.

were significantly higher in the control than in transgenic plants (Figure 7). This indicates the practical importance of transgenic plants to control leaf spot disease.

\section{RT-PCR analysis}

The reverse transcription polymerase chain reaction of 6 PCR-positive $T_{1}$ plants of the progeny plants of $\mathrm{T}_{0}-3$ detected bands in all plants, although the band brightness and thickness differed significantly. In the plantslabeledT1-1, $\mathrm{T}_{1}-3$ and $\mathrm{T}_{1}-6$, the bands were much brighter and thicker, indicating a higher number of mRNA transcripts, which in turn indicates higher chitinase expression (Figure 8). The control plants did not have this band, while in the plants labeled $T_{1}-2, T_{1}-4$ and $T_{1}-5$, the band was comparatively less bright, indicating less mRNA copies, i.e., a reduced chitinase expression.

Silicon carbide whisker-mediated transformation is probably the simplest known method of genetic transformation. It involves vortexing of target tissues together with plasmid (harboring the gene of interest) in presence of silicon carbide. Silicon carbide is micro-needle shaped, one of the hardest known substances, and is used as an abrasive and as a component of saw blades (Dunwell 2011). Studies reveal that silicon carbide whiskers have a high tensile strength, elasticity and resistance to degradation (Choi et al. 1997). In addition, their intrinsic strength is high and they are easily cleavable, producing sharp cutting edges, as needed to penetrate cell walls and ultimately the cell nucleus (Greenwood and Earnshaw 1984). Electron microscope scanning shows that whiskers penetrate into maize cell nuclei, perforating the cell and opening the way for DNA entry (Kaeppler et al. 1990). Whisker-mediated cell perforation facilitates DNA movement to the nucleus. A higher whisker quantity and prolonged shaking can increase the transformation efficiency, whereas cell survival and regeneration are adversely affected. In other words, the whisker quantity, mixing speed and survival rate have to be well-balanced to optimize the efficiency (Frame et al. 1994, Petolino et al. 2000, Mizuno et al. 2004, Keshavareddy et al. 2013). Moreover, callus age affected the transformation efficiency greatly in different crops. In Agrostis alba, best results were obtained when transformation was performed after 6 days of subculturing (Asano et al. 1991), while for cotton, 14 days were optimal (Asad et al. 2008). In two experiments for silicon carbide-mediated transformation of rice, Matsushita et al. (1999) firstly vortexed scutellum tissues of embryos together with pAct1-F plasmid harboring the GUS gene and silicon carbide in liquid medium. They observed 302 GUS spots in a $250 \mathrm{mg}$ sample. In a second experiment, they used two plasmids; pAct1-F harboring the GUS gene and pDM302 the bar gene

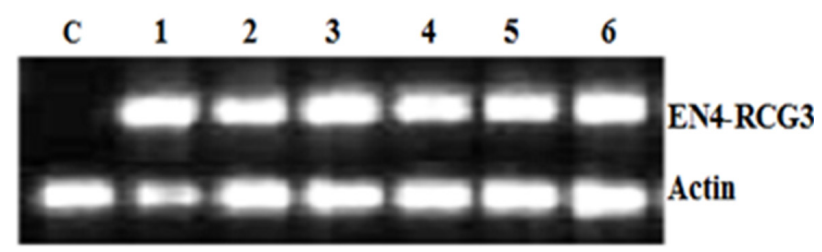

Figure 8. Six PCR-positive plants from progeny of $\mathrm{T}_{0}-3$ plant were subjected to RT-PCR analysis to obtain mRNA transcripts. 
(which confers bialaphos resistance). In the 873 embryos used in the experiment, bialaphos resistance was evidenced in 57 calli, some of which were also GUS-positive.

No report of any previous study on transformation of peanut mediated by silicon carbide whiskers was found in the literature for a comparison with this paper. The results of this study show that silicon carbide whisker-mediated transformation is a time saving and cost-effective system of insertion of a single transgene copy into legumes, particularly of peanut, without any problem of overexpression and inheritance. Moreover, the efficiency of transformation with the rice chitinase gene to control leaf spot disease in peanut was also evidenced.

\section{REFERENCES}

Appel JD, Fasy TM andKohtz DS (1988) Asbestos fibers mediated transformation of monkey cells by exogenous plasmid DNA. Proceedings of National Academy of Sciences USA 85: 7670-7674.

Asif MA, Zafar Y, Iqbal J, Iqbal MM, Rashid U, Ali GM, Arif A and Nazir F (2011) Enhanced expression of AtNHX1, in transgenic groundnut (Arachis hypogaea L.) improves salt and drought tolerance. Molecular Biotechnology 49: 250-256.

Asad S, Mukhtar Z, Nazir F, Hashmi AJ, Mansoor S, Zafar Y and Arshad M (2008) Silicon carbide whisker-mediated embryogenic callus transformation of cotton (Gossypium hirsutum L.) and regeneration of salt tolerant plants. Molecular Biotechnolgy 40: 161-169.

Asano Y, Otsuki Y and Ugaki M (1991) Electroporation-mediated and silicon carbidewhisker-mediated DNA delivery in Agrostis alba L (Redtop). Plant Science 9: 247-252.

Banjara M, Zhu L, Shen G, Payton P and Zhang H (2012) Expression of an Arabidopsis sodium/proton antiporter gene (AtNHX1) in peanut to improve salt tolerance. Plant Biotechnology Reports 6: 59-67.

Brunner F, Stintzi A, Fritig B and Legrand M (1998) Substrate specificities of tobacco Chitinases. Plant Journal 14: 225-234.

Branch WD (1996) Registration of 'Georgia Green' peanut. Crop Science 36: 806.

Choi GJ (1997) Silicon carbide fibers from copolymers of commercial polycarbosilane and silazane. Journal of Industrial and Engineering Chemistry 3: 223-228.

Chu Y, Bhattacharya A, Wu C, Knoll JE and Ozias-Akins P (2013) Improvement of peanut (Arachis hypogaea L.) transformation efficiency and determination of transgene copy number by relative quantitative real-time PCR. In Vitro Cellular and Developmental Biology-Plant 49: 266-275.

Coffee R and Dunwell JM (1994) Transformation of plant cells. United States Patent 5302523.

Dalton SJ, Bettany AJE, Timms Eand Morris P (1998) Transgenic plants of Lolium multiflorum, Lolium perenne, Festuca arundiacea, and Agrostis stolonifera by silicon carbide fibre-mediated transformation of cell suspension cultures. Plant Science132: 31-43.

Dunwell J, Frame MB, Main M, Schick R and Wang K (2011) Genetic transformation usingmaize immature zygotic embryos. In Trevor AT and Edward CY (eds) Plant embryo culture methods and protocols: methods in molecular biology. Springer Science and Business Media, Amsterdan, p. 327-341.

Frame BR, Drayton PR, Bagnall SV, Lewnau CJ, Bullock WP, Wilson HM, Dunwell JM, Thompson A and Wang K (1994) Production of fertile transgenic maize plants by silicon carbide whisker-mediated transformation. Plant Journal 6: 941-948.

Gamborg OL, Miller RA and Ojima O (1968) Nutrient requirements of suspension cultures of soybean root cell. Experimental Cell Research 50: 151-158.

Greenwood NN and Earnshaw A (1984) Silicon carbide, SiC: chemistry of elements. Pergamon Press, Oxford, 386p.

Hassan MU, Akram Z, Ajmal S, Mukhtar T, Nasim S, Shabbir G and Zafar Y (2013) Highly efficient in vitro root induction in peanut by mechanical stress method. The Journal of Animal \& Plant Science 23: 425-429.

Iqbal MM, Nazir F, Ali S, Asif MA, Zafar Y, Iqbal J and Ali GM (2012) Over expression of rice chitinase gene in transgenic peanut (Arachis hypogaea L.) improves resistance against leaf spot. Molecular Biotechnology 50: 129-136.

Kaeppler HF, Gu W, Somers DA, Rines HW and Cockburn AF (1990) Silicon carbide fiber-mediated DNA delivery into plant cells. Plant Cell Reports 9: 415-418.

Kaeppler HF, Somers DA, Rines HW and Cockbum AF (1992) Silicon carbide fiber-mediated stable transformation of plant cells. Theoretical and Applied Genetics 84: 560-566.

Keshavareddy G, Rohini S, Ramu SV, Sundaresha S, Kumar ARV, Kumar PA and Udayakumar M (2013) Transgenics in groundnut (Arachis hypogaea L.) expressing cry1AcF gene for resistance to Spodoptera litura (F.). Physiology and Molecular Biology of Plants 19: 343352.

Matsushita M, Otani M, Wakita M, Tanaki O and Shimida T (1999) Transgenic plant regeneration through silicon carbide mediated transformation of rice (Oryza sativa L.). Breeding Science 49: 21-26.

Mizuno K, Takahashi W, Ohyama T, Shimada Tand Tanaka O (2004) Improvement of the aluminum borate whisker-mediated method of DNA delivery into rice callus. Plant Production Science 7: 45-49.

Murashige T and Skoog F (1962) A revised medium for rapid growth and bio-assays with tobacco tissue cultures. Physiologia Plantarum 15: 473-497.

Mutsuddy BC (1990) Electrokinetic behaviour of aqueous silicon carbide 


\section{Mul Hassan et al.}

whisker suspensions. Journal of American Ceramic Society 9: 2747-2749.

Nagatani N, Honda H, Shimada and Kobayashi T (1997) DNA delivery into rice cells and transformation of cell suspension cultures. Biotechnology Techniques 11: 471-473.

Petolino JF, Hopkins NL and Kosegi BD (2000) Whisker mediated transformation of embryogeniccallus of maize. Plant Cell Reports 19: 781-786.

Petolino JF (2002) Direct DNA delivery into intact cells and tissues, in transgenic plants and crops. In Khachatourians GC, McHughen A, Scorza R, Nip WK and Hui YH (eds) Transgenic plants and crops. Marcel-Dekker, New York, p. 137-143.
Sela-Buurlage MB, Ponstein AS, Vloemans SA, Melchers LS, Van-den Elzen PJM and Cornelissen BJC (1993) Only specific tobacco (Nicotiana tabacum) chitinases and b-1,3-glucanases exhibit antifungal activity. Plant Physiology 101: 857-863.

Thompson JA, Drayton PR, Frame BR, Wang K and Dunwell JM (1997) Maize transformation utilizing silicon carbide whiskers: a review. Euphytica 85: 75-80.

Yun DJ, D'Urzo MP, Abad L, Takeda S, Salzman R, Chen Z, Lee H, Hasegawa PM and Bressan RA (1996) Novel osmotically induced antifungal chitinases and bacterial expression of an active recombinant isoform. Plant Physiology 111: 1219-1225. 